\title{
A Review of Archaeological Research on Saami Prehistory in Sweden
}

\author{
Inger Zachrisson
}

The prehistoric remains of the largest part of Sweden as we know it loday belonged to the circumpolar culture, out of which the Sami culture grew. Swedish archaeology has, however, concentrated on south Scandinavian culture, later to become what we call Germanic.

This article mainly deals with the Saami Iron Age. Recent research on northern Sweden deals with settlement pattern and resource utilization, iron production and forest reindeer hearding. The material from central Sweden, on the other hand is much more difficult to interpret ethnically because of the Saamis' near contact with and partial assimilation into the growing Germanic culture here - mainly a result of internal development, not of 'colonization'. The dominating view among archaeologists that the late hunter-gatherer culture here was synonymous with the Saami culture is supported by information from contemporary written sources.

Inger Zachrisson, Statens Historiska Museum, Box 5405, S-11484 Stockholm. Sweden.

"Thus, despite the fact that the culture-historic situation in Norway entails the presence of two ethnic groups, the Norwegian and the Saami (the Lapps), it is only the former who has been honoured with a History, while the Saami have 'disappeared' into the domain of ethnography - and have thus become a 'people without a history'. (...) Thus, in Norway, we have a Norwegian history and a Saami ethnography."

The Norwegian archaeologist Bjørnar Olsen's words (1986) are as valid for the situation in Sweden. It is striking how it was earlier, as in neighbouring countries, above all within ethnography and ethnology that investigations of Saami ancient monuments took place, Ernst Manker being the great name. Ethnographers study by tradition chiefly "exotic" and "primitive" peoples outside Europe, "static" societies and cultures. This constitutes a contrast to the historical-evolutionist tradition of archaeology.

How then is Saami prehistory looked upon within archaeology in Sweden? An answer is already encompassed in the title Current Swedish Archaeology.

Swedish archaeology can be said to have originated during the 17 th century, in order to provide proof of the greatness of the country. Archaeology has often been used for such purposes. The national has usually been the driving force in European archaeology.

There are still attitudes within archaeology which can be characterized as ethnocentric. The reasons are to be found partly in the social and cultural environment in which archaeology as a discipline developed and partly in the basic attitude of the theory of science with its social-Darwinistic view of the development of culture and society.

The ethnic pluralism that existed in Sweden has been ignored, virtually all attention being focused on "Swedish" prehistory.

Evolutionist currents during the 19th century influenced to a high degree Scandinavian archaeology and archaeological method in general. As far as northern Sweden is concerned, the Stone Age has been mainly associated with a hunter-gatherer economy and an egalitarian social structure, the Iron Age with an agricultural economy, farming units and a hierarchical structure, and the Middle Ages with a market economy and state authority.

The distorted concentration of the inten- 
sity of research is a consequence of the fact that only one of the two ethnic groups developed according to the traditional evolutionist model. The Saami society did not follow the model.

Thus it is, for example, generally accepted that one can write about the history of the Iron Age settlement of northern Sweden without mentioning or discussing Germanic/SwedishSaami relations, and without realizing that the subject has been neglected. Attempts to break this silence have sometimes been labelled as political misuse of archaeology, bias or a proSaami stance.

However, this attitude also originates from a great uncertainty about how to handle the situation. It is so new and so politically sensitive. It is about two totally different cultural traditions. One society has a European tradition, a written language and history. Saami history, on the other hand, is rooted in the landscape and in oral tradition.

\section{ON THE QUESTION OF THE ORIGIN OF THE SAAMIS}

In the middle of the 19 th century the common opinion among researchers of history was that the Saamis were the indigenous population of Scandinavia.

The Swedish zoologist and ethnographer Sven Nilsson claimed in 1838 , on the basis of a comparison of crania from south Swedish megaliths and late Saami graves in Varanger, that the Saamis were descended from the very first inhabitants of Scandinavia (S. Nilsson 1838-43: ch. 2).

According to the two leading archaeologists in Norway and Sweden respectively, Oluf Rygh (1872) and Oscar Montelius (1876), there had been two separate Stone Age cultures in Scandinavia, a northern, "Arctic" one and a southern one. The bearers of the Arctic culture were thought to be the ancestors of the Saamis.

However, budding nationalism and new claims to land and water rights changed this view. In 1889 the Norwegian ethnographer
Yngvar Nielsen presented so-called proof that the Saamis in southeast Norway immigrated to the area in relatively recent times from their "ancient" habitat in the north. His chief arguments were that Saami place-names were lacking there and that no recognized Saami graves or sacrificial sites had been found in the mountains of the region. The Saamis in Jämtland (south of the 64th parallel) and in Härjedalen had, according to Nielsen's theory, also arrived there fairly late (Nielsen 1891 ; cf. Zachrisson 1988a). Nielsen's theory still influences Swedish archaeology today.

However, among archaeologists, Montelius' view was generally endorsed until 1909 when the Norwegian archaeologist A. W. Brøgger put forward the view that the Saamis could not be the descendants of the Arctic Stone Age population; they did not practise advanced slate technology, pottery making or rock carving. The slate objects instead bore witness to an eastern influence (Brøgger 1909:165f).

The Swedish archaeologist Gustaf Hallström held a similar view but he thought that the Stone Age culture in northern Sweden emerged directly from that in south Sweden. According to him, the Saamis arrived from the east in c. 500 B.C., and their oldest dwelling sites were to be found in northern Finland (Hallström 1929:88).

In the 1920s and the 1930s Guttorm Gjessing in Norway was the only archaeologist arguing for cultural continuity between the hunter-gatherer culture of the north and the historically known Saami culture (Gjessing 1935).

As late as in the 1970 s the view was held that the ancestors of the Saamis immigrated to northern Sweden from the east, probably sometime between 1800 and 500 B.C. (Baudou 1974:43).

The Norwegian archaeologist Povl Simonsen was the first to point out that the previous approach was entirely wrong, and that Saami ethnicity was the result of a local process of development, about 2000 years ago (Simonsen 1980:506). Today nobody talks of immigration, but of continuity back to the 
Stone Age, at least when it comes to northernmost Norway and Sweden (see for example Baudou 1989).

Paleobotanical research has also shown that as early as c. 3000 B.C. the hunter-gatherers of northern Scandinavia were practising sporadic agriculture and keeping domestic animals, such as goats and sheep. Earlier the opinion dominated that agriculture in the north was a result of the immigration of farmers, "colonization" from southern Scandinavia. Today it is thought that it was mainly the result of internal development.

In recent years the Saamis' position as an ethnic minority in Norway has become a widely debated subject. It made the ethnicity debate within Norwegian archaeology topical, and several studies of this subject appeared in the 1970 s and 1980s. Nearly all emanated from questions of cultural identity and the emergence of Saami ethnicity or from attempts to differentiate between the Saami and the Norse.

In particular, Finner og Terfinner (1983) by the Norwegian archaeologist Knut Odner was pioneering. He proceeds from modern anthropological models, asking why and how Saami ethnicity arose. No corresponding scientific criteria were, however, advanced for "the first Norsemen" nor was any deeper analysis made of how Germanic/Norse ethnicity developed in Scandinavia.

Odner's view that Saami ethnicity arose during the Early Roman Iron Age (0)-300 A.D.) as a result of interaction between hunters in northern Fenno-Scandia and farmers in southern Finland was opposed by his colleague Bjørnar Olsen (1984; 1985). Olsen is instead of the opinion that it evolved during the first millenium B.C., as a result of contact between hunters in the north and farmers in central and east Russia.

Odner's work has also had a revolutionary influence upon archaeology in Sweden. However, a similar ethnicity debate with concentration on the Samis has not been initiated.

\section{THE SAAMI IRON AGE: A GENE- RAL SURVEY OF THE ARCHAEO- LOGICAL MATERIAL IN SWEDEN}

Current archaeological research on the Saami past is characterized by conflicting hypotheses and a paucity of archaeological data, especially from the period 300/400-1000 A.D. This applies to the whole of northern FennoScandia with the exception of the Varanger district in Norway. This period is therefore called the "void" period (Olsen 1984:63; Storli 1986).

\section{Northern Sweden}

Until the middle of the 1980s studies of the Saami Iron Age in Sweden were mostly based on different categories of ancient monuments and finds in northern Sweden, of old a generally accepted Saami area. One main way of identifying remains as Saami was by analogy with traditional Saami culture as it is known from oral tradition and written sources from the 17 th century and onwards.

Northern Sweden here includes the provinces of Lappland and Västerbotten (i.e. principally the counties of Norrbotten and Västerbotten), northern Jämtland and northern Ångermanland down to c. $63.5^{\circ}$ latitude. No Germanic/Norse settled areas are known here from the Iron Age.

The first Saami finds to be studied scientifically by Swedish archaeologists were twelve metal deposits, originally called the Lappish sacrificial sites. They contain a rich variety of metal objects mostly from the period between 1000 and 1350 A.D. of east European, northwest European and Saami types.

These finds formed the starting-point for extensive studies of contact areas, the function of the objects, manufacturing processes and the extent of production by the Saamis, the fur trade, etc (Hallström 1932; Serning 1956; Zachrisson 1984).

It was also possible to interpret some 20 contemporary silver hoards from the whole of northern Fenno-Scandia, especially Norway, as Saami (Zachrisson 1984). 
Some twenty Saami bear graves are now known from northern Scandinavia, the majority from Sweden. Most are from the 17th and 18 th centuries, but some also date from the Viking Age, i.e. c. 800-1100 (Zachrisson \& Iregren 1974; Iregren 1986). The most southerly one known so far, from Bollnäs in Hälsingland, dates from the Viking Age or earlier (Liedgren 1985).

Post-medieval Saami reindeer deposits have been investigated and different categories distinguished. Two are characteristic: "all the bones and antlers of one reindeer placed in a certain order beneath a cairn beside a large boulder", and "reindeer bones from one or more animals laid in the crevice in a cleft boulder" (Zachrisson 1985a; Iregren 1985a).

Artefacts recovered during investigations in advance of large hydroelectric power schemes formed the starting-point for the first attempts to establish criteria for Saami affiliation in dwelling-site assemblages (Zachrisson 1976). The artefacts used postdated the birth of Christ and were mostly of metal. This study was, however, restricted to the area north of the River Angermanälven, then thought to be the southern boundary of the Saamis.

A number of traditional Norse/Germanic objects and graves were interpreted as signs of Norse presence in the area. In the light of present knowledge nearly all of these would be seen as belonging to Saamis when deposited (cf. Selinge 1982; Zachrisson 1988a).

Eleven dwelling-sites of Stone Age type exhibited later Saami elements. More than 50 similar sites had radiocarbon datings from the period 1-1500 A.D. Two "void" periods were distinguished, the one discussed above and the other from c. 1300 to 1500 A.D.

A survey of faunal assemblages from the hunter-gatherer dwelling-sites in the interior of both northern and southern Norrland that were investigated in advance of dam construction, gave interesting results. The elk (Alces alces) was by far the most common animal here (Ekman \& Iregren 1984).

A number of finds of organic material, mostly objects of wood, have been made in bogs, marshes, glaciers and ice of northern Fenno-Scandia during the years. These important remnants of the ancient hunter-gatherer/Saami material culture often tend to be forgotten.

The general opinion today among specialists is that skiing was invented in the Finno-Ugric area or further east. In Sweden ancient skis, sledge runners and ackjas (small, boat-shaped sledges) are found north of limes norrlandicus (see below). Here skiing seems to have been a cultural loan from the ancient hunter-gatherer/Saami to the Germanic/Norse culture, probably mainly as a result of assimilation. New radiocarbon datings of skis found in Sweden and Norway fill in some gaps in our knowledge (Manker 1971; Berg 1950; 1970; Serning 1960; Zachrisson 1988b, ms C; Oldeberg 1956a). In early written sources mentioning the Saamis, their skiing is a recurrent characteristic (Zachrisson 1991b).

This also applies to their great skill as hunters. They had a special type of very effective bow, similar to those from east Europe and Asia. Some ancient Saami bows have been found in Sweden (Oldeberg 1956a,b).

The Saamis were also famous for their boats. A number of sewn boats are known from northern Fenno-Scandia (Westerdahl 1987).

In warm summers arrows with well preserved organic parts, such as shafts of wood and even steering feathers, have been observed near the edges of glaciers (Lundholm 1976; cf. Farbregd 1983).

The earliest description of a Saami drum and a shaman seance, in a Norwegian chronicle, dates from the 12 th century. However, the preserved drums do not seem to be that old (Zachrisson 1991a).

From the end of the 1980s two main subjects have been studied in Saami archaeology in Sweden. One is the settlement structure in northern Norrland.

During the first centuries A.D. a specialized hunting society, involving more complete dependence of the reindeer as a primary resource, seems to have emerged. The whole 
settlement system shifted westwards towards the mountain area (Forsberg 1989).

Another central question is when a differentiated Saami society started to develop.

Groups of Saami kåta (hut) platforms (earlier called "stalotomter") in the snow mountains from at least Torne träsk in the north to Namdalen (Norway) in the south have been much discussed (cf. Manker 1960; Kjellström 1983). There is general agreement that they represent summer dwelling-sites and a new utilization of the mountains from around the Viking Age. Opinions differ, however, as to whether the huts were used by Saamis with winter dwellings along the Norwegian coast during the wild reindeer hunt (Baudou 1981; Mulk 1988, thesis in preparation), or by Saamis with winter sites in the forested area east of the Keel, in what is today Sweden, for reindeer breeding (Storli 1991). The one use may not necessarily, however, exclude the other.

Extensive archaeological investigations were carried out during the 1980 s in the neighbourhood of Arjeplog in southern Lappland. A large number of hearths of different kinds belonging to Saami settlements from the 9 th to the 19 th centuries were found. The aim of these investigations was to try to interpret spatial patterns in terms of their social implications, i.e. the relationship between these and the historically known sita organization, etc. (Bergman 1988; 1990, thesis in preparation).

Forest reindeer herding in northern Sweden, A.D. 0-1800, has been the subject of new investigations. The results indicate a change of settlement pattern and resource utilization during the first millenium A.D. (Aronsson 1991). A special Saami hearth type, rectangular or of blunted oval form, dating from c. 800 to 1800 A.D. has been identified. This type of hearth was situated in the centre of a Saami kata. Its form is related to the functional division of the kata. It seems to have been in use over a large geographical area, at least as far south as the Härjedalen forests (cf. below).

Studies of the relationship between contemporary Saami settlement sites and the earlier mentioned metal hoards are being carried out in Lappland (Hedman 1989, 1990).

Iron Age hut platforms and stone-settings (graves) along the Baltic coast in northern and central Norrland are connected with a coastal hunting and fishing culture, possibly Saami (A.-C. Nilsson 1989; Olofsson \& Lindström 1990; cf. Selinge 1977: Chapter 7.1.; 1979: Chapter 5.2.). Corresponding remains in southern Norrland are less well known archaeologically (Westberg 1964).

\section{Central Sweden}

In Sweden the other main area of discussion in Saami archaeology during the last few years has been to what extent there were Saamis in central Sweden and southern Norway during the Viking Age and Early Middle Ages (Zachrisson 1988b). Today the southern border of Saami territory in Sweden is situated in Idre, northern Dalarna.

The starting-point for this research was the discovery of a Saami settlement belonging to an earlier investigated cemetery at Vivallen in north-west Härjedalen, near the Norwegian border, by the Swedish-Norwegian archaeological-osteological "South Saami Project". The dwelling-site has been radiocarbon dated to c. 800 to 1200 A.D. The so far investigated 21 flat graves with inhumation burials have been dated by the grave goods to c. 1000-1200 A.D (Hallström 1944; Zachrisson 1985b; 1985c; Sundström 1989d).

The graves were orientated in a northeastsouthwest direction. The bodies were shrouded in birchbark, a definitely Saami pre-Christian custom. The occasionally rich grave goods exhibit the very special combination of certain Saami, eastern and north-western European artefacts characteristic of Saami sacrificial sites and graves in northern Scandinavia. Foreign dress ornaments were used in a different way from that in their production areas, and this seems to be a good indicator of a different ethnic affiliation than the Finnish/ Nordic (Zachrisson 1985b).

Burials seem to have taken place during the whole of the 12 th century. Non-Christian 
graves from the agrarian settlements in the north are not known from this period.

Anthropological analyses of the skeleton material indicate Saami affiliation (Iregren 1985b; Alexandersen 1985).

The dwelling site has so far only been subject to minor excavations, revealing two kåta sites, dated to c. 800 and c. 1200 . In both the characteristic type of rectangular hearth mentioned above containing unburnt reindeer bones was encountered. A refuse heap dated to c. 1100 contained such things as bones of reindeer and goat/sheep and a piece of iron slag. Indications from different areas that the Saamis produced and worked iron throughout virtually the whole Iron Age are becoming increasingly more numerous (cf. Gert Magnusson 1986; 1989; pers. comm.; Birgitta Hulthén 1991).

A special arrowhead type dating from $c$. 1000-1200 occurs in Sweden as far south as Härjedalen and has been identified as Saami (Serning 1956; Wegraeus 1971; 1973).

In the whole of the interior of central Sweden, at least to southern Dalarna, there are remains of a late hunter-gatherer culture well into the Iron Age with unbroken links back to the Stone Age (see for example Selinge 1976; Hyenstrand 1987; Jensen 1989; Sundström 1989a; Willemark 1989).

There are fundamental differences between the ancient monuments and objects from the "hunting grounds" and those from the settled areas, differences between, on the one hand, the mobile hunter-gatherer culture in the inland and on the other, the sedentary agrarian culture along the coast. The differences are of an ecological, chorological, quantitative and grave morphological nature. In for example Jämtland and Härjedalen this difference between the two economic/social systems can be traced into the Middle Ages (Selinge 1976;1979;1982).

The hunter-gatherer culture is characterized by its dwelling-sites, pitfalls for elk/ reindeer, asbestos ware and so-called lake graves.

From the beginning, the pitfalls, mostly for elk, seem to have belonged to the ancient hunter-gatherer culture. As a rule this hunting method was not adopted by the farmers as a cultural loan until the Iron Age (Selinge 1976; 1979:63f). This loan from the Saami to the Norse culture must often have been a result of the assimilation of the former by the latter.

The lake graves in Härjedalen from around 200 B.C. to 200 A.D. have been interpreted as probably Saami (Ambrosiani, Iregren \& Lahtiperä 1984; cf. however Baudou 1988a). Other lake graves from the 6th century in northern Dalarna have been defined as Saami (Hyenstrand 1987).

Lake graves continued to characterize the hunting grounds of Härjedalen until well into the 13th century, thus covering the "void" period (Sundström 1989b). Five 6th-7th century finds from this province with an abundance of iron objects, formerly named (iron) hoards, are probably graves also belonging to the hunter-gatherer culture (Sundström 1989c).

The lake graves are usually situated on or beside a dwelling-site belonging to the ancient hunter-gatherer culture. The spatial relationship is incontestable, even if contemporaneity is still not proven, probably due to a paucity of investigations (Selinge 1979:56ff, $87 \mathrm{ff}$ ). It is striking how often the word finn (the west Nordic word for Saami), lapp (used in the east Nordic/Finnish area) or words with derogatory overtones by tradition can be connected with lake graves in Jämtland, Härjedalen and Medelpad. Sometimes there is an oral tradition to the effect that Saamis were buried at the place (Selinge 1976; 1984:49f).

It should be possible to find dwellingsites from the "void" period in connection with lake graves.

The discussion regarding the southern extension of the Saami culture is closely associated with the interpretation of this late huntergatherer culture. Today more and more scholars are of the opinion that it is synonymous with the Saami culture, even though most archaeologists express this view very carefully or implicitly (e.g. Hemmendorff 1989:23f). On the other hand, the old view of an ethnic 
boundary between Saamis and Norsemen somewhere along the 64th parallel was expressed as late as in the 1980s (Baudou 1981:142 et al; 1986:23 et al; 1988b:236 et al; 1989; Selinge 1979:190; see Zachrisson 1988a:73ff).

The view that there was a large Saami area in the south is supported by the written sources. From Tacitus in 98 A.D. and onwards the Saamis are referred to by various names, fenni, scridefinnas, finnar (skrida probably refers to skrida á skídum, 'to ski'). West Nordic written sources from the early Middle Ages refer to finnar in Oppland, i.e. south-east Norway, and (probably) in Härjedalen (Zachrisson 1991b).

It thus seems relevant to see most of the inland as the home of the Saami population during the Iron Age instead of as one large outfield area for the Norse settlements, as is sometimes the case.

\section{THE RELATIONSHIP BETWEEN THE SAAMI, NORSE AND FINNISH CULTURE}

Studies of north Swedish grave material have provided many examples of interaction between the Saamis and their neighbours.

Grave customs can evidently be adopted by one ethnic group from another. For example, the local (Saami) population in Härjedalen seems to have adopted a new grave custom in c. $400 / 200$ B.C. as a result of interaction with another ethnic group (Germanic/Norse), probably in the Mälaren valley. This contact may have been occasioned by an interest in products from the north such as furs. Other characteristics of these graves indicate, however, that the religion of the local population was preserved.

Grave customs are good indicators of interaction. Other graves show that during the whole of the first millenium A.D. one area after the other in the inland hunting grounds came into close enough contact with settled areas to adopt certain grave customs. The Långön cemetery in Ångermanland, for ex- ample, not only reflects the custom of building mounds over burials, but also shows that the burial customs of the settled areas were copied when the settled area changed from cremation to inhumation (Zachrisson Ms A).

Norse and eastern bronze and silver objects from the Viking Age are found in northern Swedish graves and stray finds. Most of the stray finds probably derive from graves. It has been possible to show that in principal these objects were owned by Saamis at the time of deposition. The Saami grave customs in the area at that time were heterogeneous, indicating interaction with different parts of Fenno-Scandia. Grave forms, grave customs (with the exception of birchbark shrouds) and grave goods thus do not seem to be bound to ethnic group. The placing of graves on promontories, islands and islets seems, on the other hand, to characterize Saami affiliation in this area (Zachrisson 1988a).

Study of Viking Age and early medieval bronze and silver objects of "eastern" types, from the whole of north Sweden and the ancient monuments from which they derive reveals interesting indications of the interaction pattern. For example, eastern objects from the 9 th and 10th centuries can be divided into those of Finno-Ugric-East Baltic origin and those of "Russian"-oriental origin. The former all seem to be connected with Saami ancient monuments, while the latter are associated with their Norse counterparts in the settled areas (Zachrisson 1987).

Periods of prosperity in the Nordic settled areas of the north, readable in silver hoards, succeeded each other in time from south to north. The settled areas in Medelpad and Hälsingland seem to have experienced their boom in the 6th century, whereas those in Angermanland reached an economic climax in the Viking Age. This surplus may have had its roots in intensified exploitation of inland resources, by Norsemen (Zachrisson 1988a; cf. Selinge 1977:401f).

Traditional Saami culture, material as well as spiritual, shows many traits from Norse Viking Age and early medieval culture, traits 
which had long since gone out of use among the Norsemen. The reason could be that these elements still fulfilled a function in Saami but not in Norse society. However, the reason may also be so-called culture fixation, a sign of a Saami boom during these periods ( $\mathrm{Za}-$ chrisson 1984).

Studies of different boundaries in the north have been carried out.

Of special interest is the so-called limes norrlandicus, transversing northernmost Dalsland, southern Värmland, Västmanland and northern Uppland. It is the southern boundary of the ancient Stone Age hunter-gatherer culture of the circumpolar region (cf. Selinge 1980). To what extent was this an ecological boundary and to what extent was it cultural? Was it once an ethnic boundary? (Zachrisson Ms B). Why and when this border arose and for how long it lasted are important tasks for future research.

\section{ARCHAEOLOGY AND POLITICS}

In Norway there was intense public debate in the 1970s and 1980s as to whether or not the Saamis were an "indigenous" people according to the international ILO-Convention. Debate soon focused upon historical "evidence" and upon archaeology (cf. Schanche \& Olsen 1985).

Bjørnar Olsen concluded (1986:37): "Archaeologists do not carry out research in a vacuum, but in a contemporary context of socio-political struggles. (...) Refusing to take a political standpoint is a political stand in itself, which serves the ruling interests - the status quo. (...) when one indirectly serves the ruling interests by not opposing them, one is not 'political', which happens only when one's views are in contrast with the 'normal', accepted values. (...) Therefore, a scholar is a political person despite his/her personal wishes, and archaeology is, if anything, politics!"

For more than ten years a Saami Rights Commission, Samerettsutvalget, has been at work in Norway. In 1986, as a direct result of the investigations at Vivallen, the task of writing the history of the South Saamis, originally given to two historians, was expanded. It now includes investigations by two linguists (of place-names) and two archaeologists (see Stenvik \& Zachrisson 1988).

The Vivallen results have also played an important role in strengthening the identity of the South Saamis in both Sweden and Norway (Zachrisson 1991c).

A major court case about the Saamis' right to winter grazing in the whole of Härjedalen below the area of the so-called reindeer grazing mountains or skattefjäll has just started (Sept. 1991). In 1990 three large forestry companies and about 700 land-owners in Härjedalen sued the five Saami sitas in Härjedalen, Dalarna and southernmost Jämtland. Saami rights are founded on practice from time immemorial. The archaeological results proving an early (Saami) history in the province have already been referred to.

\section{CONCLUDING REMARKS; FUTURE RESEARCH}

The general view is that we still lack real archaeological evidence of Saami settlement before the Viking Period.To a certain extent this may be correct, but it is above all a lack of understanding and recognition of what are in fact prehistoric Saami monuments.

A great deal of research is today being conducted into late hunter-gatherer Saami culture in northern Sweden and Germanic/ Norse culture in central Sweden. Studies, investigations and fruitful discussions concerning the late hunter-gatherer culture in central Sweden are lacking.

Archaeological sites along the coast of the Baltic are very little known. Should they be seen in a Saami context or not?

Iron production is an important field. New studies of asbestos ceramics are said to indicate that this pottery was used for iron production. These results may shed totally new light on the activities of the Early Iron Age in relation to Saami culture.

We can probably count on a stratified 
Saami society from at least c. 800 A.D., i.e. the Viking Age. For most of northern and central Sweden problems regarding the true relationship between the continuing use of the old dwelling-sites, and other, "new" ways of living remain.

For the whole of the area in which lake graves are encountered, $i$. $e$. from southernmost Lappland to south Dalarna, we have a unique chance of finding the contemporaneous dwelling-sites connected with these graves. Locating and excavating these must be a main task for this huge area. We know too little about what a hunter-gatherer dwelling-site from the Iron Age really looked like.

In this part of Sweden the "void" period actually seems to last from c. 400 to 800 A.D. However, some lake graves and finds from the setting we are interested in date from this period, as for example the iron hoards/graves from Härjedalen. New analyses of the existing material, monuments as well as objects, in combination with new excavations ought to give results.

From the Stone Age and onwards there are traces of contact between the circumpolar hunter-gatherer culture in the north and the South Scandinavian culture.

A study of different types of contact between members of the two main cultures, the Saami and the Norse, especially in "border" areas such as the Storsjö area in Jämtland, could produce a more concrete and vivid picture of the past. What can reality have looked like: cooperation, trade, marriage, assimila- tion or the opposite? Are the contrasts or the similarities the dominant features?

Further exchange of ideas, knowledge and results with other disciplines is fundamental.

Collaboration with linguists is essential. The study of place-names and the landscape they are situated in is especially important. What do they tell of the use of the landscape, the people who used it and when it was used?

There is a real "research gap" here; Saami place names are difficult to date, because too little research has been done on them. We lack qualified specialists with knowledge both of the different Saami and the different Norse languages or dialects. Names have been altered, distorted, changed and intermixed in the course of interaction between the two large language areas.

More use of generalized anthropological principles and direct ethnohistorical evidence of other hunter-gatherer cultures, especially those in Siberia, might provide a better understanding of early Saami spiritual life.

New investigations are today being conducted by geologists concerning the retreat of the latest ice-sheet in its northern part. The results of this may make for a better understanding of when man could have moved into different areas. Perhaps this will reinforce the two-culture view of Swedish prehistory of which can already be inferred from genetic as well as archaeological research.

English revised by Jacqueline Taffinder. 


\section{REFERENCES}

Alexandersen, V. 1985. Odontologisk undersqkelse af skeletmateriale fra gravfellet på Vivallen i Funäsdalen. Sörsamiska projektet, rapport 5.

Ambrosiani, B, Iregren, E. \& Lahtiperä, P. 1984. Gravfall i faingstmarken. Undersökningar av graväalten på Smalnäset och Krankmairtenhögen. Härjedalen. (Riksantikvarieämbetet och Statens historiska museer rapport 1984:6.) Stockholm.

Aronsson, K.-Å. 1991. Forest Reindeer Herding A.D. I1800. An archaeological and palaeoecological study in northern Sweden. (Archaeology and Environment 10.) Umeå.

Baudou, E. 1974. Samernas invandring till Sverige ur arkeologisk synpunkt. Sameforskning $i$ dag och $i$ morgon. (Nordiska museets jubileumssymposier.) Stockholm.

- 1981. Förändringar inom jägarkulturen vid Lule älv. Luleälvssimposiet I-3 juni 1981. (Skrifter frăn Luleälvsprojektet 1.) Umeă.

- 1986. Ortmamn och nordliga kulturprovinser under jürnålder och medeltid. Tre kulturer 3. Medlemsbok för Johan Nordlander-sällskapel. Umeå.

- 1988a. Samer och germaner i del förhistoriska Norrland. En kritisk översikt över tio års forskning. Sameroch germaner. (Bebyggelsehistorisk tidskrift 14, 1987).

- 1988b. Norrlands förhistoria. In: G Burenhult: Länkar till vår forntid - en introduktion i Sveriges arkeologi. Stockholm.

- 1989. Stability and Long Term Changes in North Swedish Prehistory. An Example of Centre-Periphery Relations. Approaches to Swedish Prehistory. A Spectrum of problems and perspectives in conlemporary research. Ed. Th. B. Larsson \& H. Lund mark. (BAR International Serics 500.)

Berg, G. 1950. (1941). The origin and the development of the skis throughout the ages. Finds of skis from prehistoric time in Swedish bogs and marshes. Stockholm.

- 1970. Skidor. Kulturhistoriskt lexikon 15. Malmö. Bergman, I. 1988. Det samiska boplatskomplexet vid Racklräsk. Arjeplog. Arkeologi i norr 1. Arkeologiska institutionen. Umeå universitet.

1990. Rumsliga strukturer i samiska kulturlandskap. En studie med utgångspunkt i två undersökningar inom Arjeplogs socken. Lappland. Fornvännen.

Brøgger, A.W. 1909. Den arktiske stenalder i Norge. Skrifter udg. af Videnskabs-selskabet i Christiania. II. Hist.fil klasse.

Ekman, J. \& Iregren, E. 1984. Archate-Zoological Investigations in Northern Sweden. (Early Norrland 8.) Stockholm.

Farbregd, O. 1983. Snøfonner, pilefunn og dyregraver. Det Kgl. Norske Videnskabers Selskab Museet. Rapport. Arkeologisk serie 1983:5. A rshefte 1983.
Forsberg, L. 1989. Economic and Social Change in northern Sweden 6000 B.C. - 1000 A.D. Readings in Saami History, Culture and Language. Ed. N. Broadbent. (Center for Arctic Cultural Rescarch. Misc. Publ. 7.) Umeå.

Gjessing, G. 1935. Fra steinalder til jernalder i Finnmark. Instituttet for sammenlignende kulturforskning. serie C III-3. Oslo.

Hallström, G. 1929. Kan lapparnas invandringstid fixeras? Nomlands Försvar. Stockholm.

- 1932. Lapska offerplatser. Arkeologiska studier tillagnade HKH Kronprins Gustaf Adolf. Stockholm.

- 1944. Gravfältet pă Vivallen i Funäsdalen. Heimbygdas tidskrift. Fornvärdaren 8 . Östersund.

Hedman, S.-D. 1989. Samiska metalldepåer och bosätt ningsmönster $\mathrm{i}$ Lappland under vikingatid och äldre medelıid. Arkeologi i norr 2. Umeå.

- 1990. Undersökningar av vikingatida och medeltida bosättningar i Lappland. Arkeologi i norr 3. Umeå.

Hemmendorff, O. 1989. Inledning. Arkeologi i fjäll, skog och bygd. I. Stenàlder-tidig jämailder. (Fornvårdaren 23.) Jämtlands läns museum. Östersund.

Hulthén. B. 1991. On Ceramic Ware in Northern Scandinavia During the Neolithic, Bronze and Early Iron Age. A Ceramic-Ecological Study. (Archaeology and Environment 8.) Umeå.

Hyenstrand, А. 1987. Forntid i gränsland. Lima och Transtrand. Ur två socknars historia. Malung.

Iregren, E. 1985 a. Osteological evaluation of rcindeer bone linds from the territory of the Southern Saamis. Arr. Scandinavian Yearbook of Folklore 1983. 39 .

- 1985b. The Ethnic Grouping of Populations. The Vivallen Cemetery as an Example of a Methodological Study in Physical Anthropology. In Honorem Ever Baudou. (Archaeology and Environment 4.) Umeå.

- 1986. Samernas rituella björngravar. Populär Arkeologi 4.

Jensen, R. 1989. Hällbilder och făngstboplatser. Arkeologi ifjäl, skog och bygd. 1. Sienalder-tidig jämalder. (Fornvårdaren 23.) Jämtlands läns museum.

Kjellström, R. 1983. Staloproblemet i samisk historia. Folkogressurser inord. Foredrag fra Trondheimssvmposictom midt-ognordskandinavisk kultur 1982. Trondheim.

Liedgren, L. 1985. Gustaf Hallström's Excavation at Onbacken, Hälsingland, 1923. In Honorem Evert Baudou. (Archaeology and Environment 4.) Umeă. Lundholm, K. 1976. Två kompletta pilar från Lappland. Fonvinnen 71 .

Magnusson, G. 1986. Lågteknisk järnhamtering i Jämtlands län. (Jernkontorets Bergshistoriska Skriftserie 22.) Stockholm.

1989. Järnålder på Rödölandet. Arkeologi i fjäll. skog och bygd. 2. Järnålder-medeltid. (Fornvårdaren 24.) Jämtlands läns museum. Östersund. 
Manker, E. 1960. Fangstgropar och stalotomter. Kulturlämningar frain lapsk forntid. (Acta Lapponica 15.) Stockholm.

- 1971. Fennoskandias fornskidor. Preliminär rapport från en inventering. Fornvännen.

Montelius, O. 1876. Sur les souvenirs de l'âge de la pierre des lapons en Suéde. Congrés international d'anthropologie \& d'archéologie préhistoriques. Compte rendue de la 7 esession, Stockholm, 1874. Tome premier.

Mulk, I.-M. 1988. Sirkas - ett fjällsamiskt fångstsamhälle i förändring $500-1500$ e Kr. Samer och germaner. (Bebyggelsehistorisk tidskrift 14, 1987.)

Nielsen, Y. 1891. Lapparnes fremrykning mod syd i Trondhjems stift og Hedemarkens amt. Det norske geografiske selskabs ärbog 1, 1889-1890. Kristiania.

Nilsson, A.-C. 1989. Tomtningar frăn yngre jämåldern utmed Öve Norrlands kust. (Center for Arctic Cultural Research, Umeå University. Research Reports 13.)

Nilsson, S. 1838-1843. Skandinaviska Nordens Ur-Invanare, elt försök $i$ komparativa ethnografien och ett bidrag till menniskoslägtets utvecklingshistoria. Del 1. Lund.

Odner, K. 1983. Finner og terfinner. Etniske prosesser $i$ det nordlige Fenno-Skandinavia. (Oslo Occasional Papers in Social Anthropology No. 9.) Oslo.

Oldeberg, A. 1956a. "Tjautjerfyndet" i Västerbotten och några paralleller till de däri ingăende föremålen. Fornvämnen.

1956b. Bågfyndet från Jokkmokk. Norrbotten.

Olofsson, L. \& Lindström, I. 1990. Fiskelägen och tomtningar i västra Bottenvikens skärgård. Uppsats i C 1 i arkeologi, Umei univ., Institutionen för arkeologi.

Olsen, B. 1984. Stabilitet og endring. Produksjon og samfunn i Varanger 800 f.Kr. -1700 e.Kr. Magistergrad i arkeologi. Univ. i Tromsф.

- 1985. Comments on Saamis, Finns and Scandinavians in History and Prehistory. Norwegian Archaeological Review 18. 1985:1-2.

- 1986. Norwegian archacology and the people without (pre-)history: or how to create a myth of a uniform past. Archaeological Review from Cambridge volume 5:1. Archaeology ef Politics. Spring 1986.

Rygh, O. 1872. On Affaldsdyngen ved Stenkjaer. Årsberetning fra foreningen til norske fortidsmindesmerkers bevaring 1871 . Kristiania.

Schanche, A. \& Olsen, B. 1985. Var de alle norrmen? En etnopolitisk kritikk av norsk arkeologi. Arkeologi og etmisitet. (AmS-Varia I5. Arkeologisk museum i Stavanger.) Stavanger.

Selinge, K.-G. 1976. Människan i landskapet. Förhistoriska kulturmiljöeri Jämtland och Härjedalen. (Fornvårdaren 14.) Östcrsund.

1977. Järnålderns bondekultur i Västernorrland. In: Baudou \& Selinge: Västemorrlands förhistoria. Härnösand.

- 1979. Agrarian Setlements and Hunting Grounds.
(Theses and Papers in North-European Archaeology 8.) Univ. of Stockholm. Stockholm.

- 1980. Fasta fornlämningar på kartor och i register. Suensk lantmäteritidskrift 1980:5.

1982. Comments on Economic Change and the Prehistoric Fur Trade in Northern Sweden: The Relevance of a Canadian Model. Norvegian Archaeological Review 15:J-2.

- 1984. Att bruka ett landskap. Medelpad. Svenska Turistföreningens årsskrift.

Serning, I. 1956. Lapska offerplatsfynd frän järnålder och medeltid $i$ de svenska lappmarkerna. (Acta Lapponica 11.) Stockholm.

- 1960. Övre Norrlands järnålder. (Skrifter utg. av Vetenskapliga biblioteket i Umeå 4.) Umeå.

Simonsen. P. 1980. Veidemenn på Nordkalotten. Hefte 3: Yngre steinalder og overgang til metallid. (Stencilserie B -historie. Nr 17. Institutt for samfunnsvitenskap, Univ. i Tromsö.)

Stenvik, L. \& Zachrisson, I. 1988. Arkeologisk materiale som grannlag for sluminger om sorsamisk historie. Utredning for Samerettsutvalget. Trondheim \& Stockholm.

Storli, I. 1986. A review of archaeological research on sami prehistory. Acta Borealia I. Vol. 3.

- 1991. "Stallo"-boplassene. Et tolkningsforslag basert på undersokelser i Lonsdalen, Salifjellet. Institutt for samfunnsvitenskap, Univ. i Troms $\varnothing$.

Sundström, J. 1989a. Juvuln - 3000 år i fjällnära fångst land. Arkeologi ifjall, skog och bygd. l. Stenaldertidig järnålder. (Fornvårdaren 23.) Jämtlands läns museum.

- 1989b. Järnåldersgravar i fångstlandet. Arkeologi i fjäll. skog och bygd. 1. Stenålder-tidig järnålder. (Fornvårdaren 23.) Jämtlands läns muscum.

- 1989c. Rika järnfynd från Härjedalen. Arkeologi $i$ fjäll, skog och bygd. 2. Järnälder-medeltid. (Fornvårdaren 24.) Jämtlands läns museum.

- 1989d. Med Vivallen som utgångspunkt - nya undersökningar. Arkeologi ifjall, skog och bygd. 2. Järnålder-medeltid. (Fornvårdaren 24.) Jämtlands läns museum.

Wegraeus, E. 1971. Vikingatida pilspetsar i Sverige - en förbisedd foremålsgrupp. Del I-H. (Lic.-avhandl. i Nordisk o jfr fornkunskap, Uppsala.)

- 1973. Pilspetsar under vikingatid. Tor 15, 19721973.

Westberg. H. 1964. Lämningar efter gammal fångstkultur i Hornslandsområdet. Fornvämnen 59.

Westerdahl, C. 1987. "Et sät som liknar them uti theras ifriga lefnadsart". Om äldre samiskt baitbygge och samisk bathantering. (Skrifter utgivna av Johan Nordlander-sällskapet Nr 11.) Umeå.

Willemark, K. 1989. Ödingen - en uppehållsplats genom förhistorien. Arkeologi ifjäll, skog och bygd. l. Stenålder-tidig jämålder. (Fornvărdaren 23.) Jämtlands läns museum.

Zachrisson, 1. 1976. Lapps and Scandinavians. Archaeological Finds from Northern Sweden. (Early Nortland 10.) Stockholm. 
- 1984. De samiska metalldepäerna àr 1000-1350i liuset av fyndet frän Mörträsket, Lappland. (The Saami Metal Deposits A.D. 1000-1350 in the light of the find from Mörtträsket, Lapland.) (Archaeology and Environment 3.) Umeå.

1985a. New archaeological finds from the territory of the Southern Saamis. Arv. Scandinavian Yearbook of Folklore 1983. 39.

- 1985b. Saami or Nordic? A Model for Ethnic Determination of Northern Swedish Archaeological Material from the Viking Period and the Early Middle Ages. In Honorem Evert Baudou. (Archacology and Environment 4.) Umeå.

- 1985c. Comments on Saamis, Finns and Scandinavians in History and Prehistory. Nomegian Archacological Review 18:1-2.

- 1987. Östliga kontakter under nordsvensk vikingatid och tidig medeltid. Nordkalotten i en skiftande värld-kulturer utan gränser och stater över gränser. (Studia Historica Septentrionalia 14:1.) Rovaniemi.

- 1988a. The So-called Scandinavian Cultural Boundary in Northern Sweden in Viking Times - Ethnic or Socio-Economic? A Study Based on the Archaeological material. Acta Borealia /-2. Troms $\phi$.

- 1988b. Arkeologi och etnicitet. Samisk kultur i mellersta Sverige ca $1-1500$ e Kr. Samer och germaner. (Bebyggelsehistorisk tidskrift 14, 1987.) Stockholm.
- 1991a. The Saami Shaman Drums. Some Reflexions from an Archaeological Perspective. The Saami Shaman drum. (Scripta Instituti Donneriani Aboensis XIV.) Ed T Ahlbäck, J Bergman. Åbo.

- 1991b. The South Saami Culture: in Archaeological Finds and West Nordic Written Sources from AD 800-1300. Social Approaches to Viking Studies. Ed R Samson. Glasgow.

- 1991c. Samisk arkeologi - reaktioner jag mött. Samesymposium. Red M Aikio, K Korpijaakko. Lapplands univ. Förvalıningsämbetets publikationer 15. Rovaniemi.

- Ms A. Can grave customs be taken over by one ethnic group from another? Saami and Germanic traits in early Iron Age graves from northern Sweden. Paper given at IAHR Regional Conference on Circumpolar and Northem Religion, Helsingfors university, May 1990.

- Ms B. Olika typer av gränser under Nordsveriges järnalder. Paper given at the symposium Kulturgränser - myt eller verklighet?, Umeå university, November 1990.

- Ms C. Samisk kultur i Finland under järnåldern. Paper given at Congress on Finnish Early History, Uleåborg university, in Torneå, June 1991.

Zachrisson, I. \& Iregren, E. 1974. Lappish Bear Graves in Northern Sweden. (Early Norrland 5.) Stockholm. 